Research Article

\title{
Simultaneous Photocatalytic Esterification and Addition Reaction of Fatty Acids in Kemiri Sunan (Reutealis trisperma sp.) Oil Over $\mathrm{CuO} / \mathrm{TiO}_{2}$ Catalyst - A Novel Approach
}

\author{
Athiek Sri Redjeki, S. Sukirno, S. Slamet* \\ Department of Chemical Engineering, Faculty of Engineering, Universitas Indonesia \\ Kampus UI Depok, Depok 16424, West Java, Indonesia.
}

Received: $8^{\text {th }}$ July 2021; Revised: 29th August 2021; Accepted: 4th September 2021

Available online: $6^{\text {th }}$ September 2021; Published regularly: December 2021

\section{Abstract}

A novel approach, namely photocatalytic esterification and addition reaction of unsaturated fatty acids using $\mathrm{CuO} / \mathrm{TiO}_{2}$ catalyst has been investigated in kemiri sunan oil. The objectives of this study are to reduce the free fatty acid (FFA) content by using catalyst $\mathrm{CuO} / \mathrm{TiO}_{2}$, characterization of the catalyst and the operation condition of reaction. The $\mathrm{CuO} / \mathrm{TiO}_{2}$ catalyst was synthesized by the impregnation of $\mathrm{TiO}_{2}$ P25 powder with copper nitrate solution as a precursor and followed by calcination. The field emission scanning electron microscopy (FESEM), Energy Dispersive X-ray (EDX), X-ray Diffraction (XRD), and Transmission electron microscopes (TEM) result showed that copper oxide was highly dispersed on the $\mathrm{TiO}_{2}$ surface. The X-ray Photoelectron Spectroscopy (XPS) result showed that $\mathrm{Cu}$ is in the state of $\mathrm{CuO}\left(\mathrm{Cu}^{2+}\right)$, while $\mathrm{Ti}$ is in $\mathrm{Ti}^{4+}\left(\mathrm{TiO}_{2}\right)$. The bandgap energy of $\mathrm{CuO} / \mathrm{TiO}_{2}$ was smaller than $\mathrm{TiO}_{2}$ P25. It was found that the reactions conducted in the presence of $\mathrm{CuO} / \mathrm{TiO} 2$ in a photoreactor under UV irradiation can perform esterification and addition reaction of the FFA, simultaneously. The optimum reduction of the FFA was under condition of $4 \%$ loading $\mathrm{CuO} / \mathrm{TiO}_{2}, 4$ hours reaction time, $30: 1$ (mole/mole) methanol to oil ratio, 5\% (w/w) catalyst amount. The conversion of FFA was at around 59\%. The Gas Chromatography-Mass Spectrometry (GC-MS) results showed that the addition reaction of $\alpha$-eleostearic acid simultaneously occured at $100 \%$ conversion. Although the photocatalyst selectivity in FFA reduction was relatively low, but double bond reduction of $\alpha$-eleostearic acid (C18:3) was very high. The reduction of multiple double bond is considered as positive poin to improve the oxidative stability of the product. The simultaneous esterification and addition reactions mechanism has been proposed.

Copyright (C) 2021 by Authors, Published by BCREC Group. This is an open access article under the CC BY-SA License (https://creativecommons.org/licenses/by-sa/4.0).

Keywords: addition reaction; esterification; kemiri sunan oil; simultaneous photocatalytic esterification; $\mathrm{CuO}_{2} \mathrm{TiO}_{2}$

How to Cite: A.S. Redjeki, S. Sukirno, S. Slamet. (2021). Simultaneous Photocatalytic Esterification and Addition Reaction of Fatty Acids in Kemiri Sunan (Reutealis trisperma sp.) Oil over $\mathrm{CuO} / \mathrm{TiO}_{2}$ Catalyst - A Novel Approach. Bulletin of Chemical Reaction Engineering \& Catalysis, 16(4), 816-830 (doi:10.9767/bcrec.16.4.11690.816-830)

Permalink/DOI: https://doi.org/10.9767/bcrec.16.4.11690.816-830

\section{Introduction}

Kemiri Sunan (Reutealis trisperma) oil has a high potential to be a feedstock in producing methyl esters [1,2], which are the main

\footnotetext{
* Corresponding Author.

Email: slamet@che.ui.ac.id (S. Slamet)
}

components of eco-green surfactant (methyl ester sulfonate-MES) [3] and bio-fuel (fatty acid methyl esther-FAME) [4]. Fatty acid methyl ester (RCOOR') has advantageous characteristics, such as: non-toxic, sulphur free, renewable, and biodegradable [5]. It can be synthesized from vegetable oil including palm, soybean, rapeseed, sunflower, etc. by transesterification process using strong base catalysts [6-9]. 
As non-edible oil, Kemiri Sunan oil does not compete with foods and it has more excellence properties due to about $62 \%$ of oil content. However, it has a high content of free fatty acids (FFA) and is composed of many polyunsaturated compounds such as $\alpha$-eleostearic acid (C18:3) which limit its use [10-12]. The presence of high FFA during transesterification will cause saponification, which makes it difficult to separate between methyl esters and glycerols [13]. Esterification is needed to avoid the saponification. Conventional esterification usually applies using acid catalysts [14], a homogenous process with a strong acid solution. Acid catalyst has advantages, including the ease to homogenize and to give higher conversion. However, its disadvantages would be the difficulty to separate the product, the high methanol to oil molar ratio, the need for equipment with corrosion resistance, and the need for heating to around the boiling point of methanol [15]. Hence, the heterogenous catalyst are required to replace the homogenous. The use of heterogenous catalyst is expected to overcome this weakness, because it was easily separated and did not require neutralization [16]. One of heterogenous catalyst that can used is a photocatalyst that can provide an additional advantage: allowing the esterification to occur at room temperature.

Photocatalytic esterification has been studied by Corro et al. $[17,18]$, who used $\mathrm{ZnO} / \mathrm{SiO}_{2}$ for converting the FFA content of Jatropa curcas and $\mathrm{Cr} / \mathrm{SiO}_{2}$ for waste frying oil. Manique et al. [5] studied photocatalytic esterification of oleic acid using nanotube $\mathrm{TiO}_{2}$ and Verma et al. [19] studied that of acetic acid using activated $\mathrm{TiO}_{2}$. The catalysts are highly active for the esterification and can be reused ten times. Corro and Manique [5,17,18] also proposed the photocatalytic esterification mechanism. However, they have not discussed the possibility of photocatalytic esterification and addition reaction simultaneously.

Among the photocatalysts, titanium dioxide $\left(\mathrm{TiO}_{2}\right)$ has been widely used as a photocatalyst due to its chemical and physical characteristics. [20]. However, the disadvantages are the rapid recombination between photogenerated conduction band (CB) electrons and valence band (VB) holes and high bandgap energy $(\sim 3.2 \mathrm{eV})$ that make it only can be active under UV light [21]. To avoid it can be modified by $\mathrm{TiO}_{2}$ conjunction with a metal dopant, such as $\mathrm{Cu}$, which act as an electrons trapper. The conjuction will also decrease the bandgap energy of $\mathrm{TiO}_{2}$ and increase its photo response to visible light [22]. The $\mathrm{CuO} / \mathrm{TiO}_{2}$ composite has been carried out in areas, such as: for degradation diclofenac [23], $\mathrm{CO}_{2}$ [24], and the production of hydrogen from water [25-27]. Based on the $\mathrm{CuO} / \mathrm{TiO}_{2}$ photocatalyst ability that can convert water into hydrogen and oxygen, it is predicted that other phenomena can occur during esterification, such as: the hydrogen addition of unsaturated fatty acids due to the presence of hydrogen in the catalyst surface [28]. To the best of our knowledge, there have never been studies that dealt with esterification and the addition reaction of non-edible oil simultaneously using $\mathrm{CuO} / \mathrm{TiO}_{2}$ as a catalyst. By using the same catalyst $\left(\mathrm{CuO} / \mathrm{TiO}_{2}\right)$ for esterification and addition reaction, it is expected to provide added value of catalyst and to improved the oxidative stability of the product

The use of Kemiri Sunan oil for biofuel is not preferable due to the high number of containing poly-unsaturated methyl ester (C18:3) that can react with oxygen and form peroxides. At unsaturated bonds can occur crosslinking and can be polymerized into plastic-like objects. At high temperatures, the presence of that polymerized methyl esters could induce the internal combustion engine become sticky [29]. The addition of unsaturated fatty acid will reduce the unsaturation level and increase the potential of Kemiri Sunan oil as biofuel feedstocks.

In this study, we investigated the $\mathrm{CuO} / \mathrm{TiO}_{2}$ ability for photo-esterification and the photoaddition of unsaturated fatty acid in Kemiri Sunan oil. The effect of $\mathrm{CuO}$ loading in $\mathrm{TiO}_{2}$ to its morphology, crystallite, light absorption and the chemical state of $\mathrm{Cu}$ are studied. The effect of several variables, such as: reaction time, $\mathrm{CuO}$ loading, catalyst amount and the molar ratio of oil:methanol to the conversion of FFA and a-oleostearic acid, were also studied. The photocatalytic esterification and addition reaction mechanism prediction is presented and discussed.

\section{Materials and Methods}

Kemiri Sunan oil (containing 13.62\% Palmitic acid; $4.92 \%$ of stearic acid; $14.18 \%$ of oleic acid; $16.9 \%$ of linoleic acid; and 41.80 of aoleostearic acid) was purchased from local market in Bandung, Indonesia. Methanol (Merck, PA), $\mathrm{TiO}_{2}$ powder (aeroxide P25, Evonik), aquadest, copper nitrate $\left(\mathrm{Cu}(\mathrm{NO})_{3 .} 3 \mathrm{H}_{2} \mathrm{O}\right)$ were purchased from Merck, P.A. All chemicals are used under the same conditions as when they were purchased. 


\subsection{Catalyst Preparation}

The preparation of $1,2,3,4,5$, and $6 \%$ $\mathrm{CuO} / \mathrm{TiO}_{2}$ photocatalyst was obtained using copper nitrate as a $\mathrm{Cu}$ precursor by wet impregnation, followed by a calcination process. A total of 5 grams of $\mathrm{TiO}_{2}$ was suspended in 400 $\mathrm{mL}$ of aquadest to be mixed in a magnetic stirrer for 15 minutes. The suspension then was sonicated for 30 minutes. Certain amount of copper nitrate powder (each 0.1519, 0.3038, $0.4457,0.6075,0.7594$, and $0.9113 \mathrm{~g}$ ) was diluted in $50 \mathrm{~mL}$ of aquadest. The solution was then impregnated in the $\mathrm{TiO}_{2}$ suspension and stirred at room temperature for 2 hours at $500 \mathrm{rpm}$, followed by a drying process at $180{ }^{\circ} \mathrm{C}$ until forming dried granules. The $\mathrm{CuO} / \mathrm{TiO}_{2}$ granules produced were then calcinated in a furnace at $300{ }^{\circ} \mathrm{C}$ for 2 hours.

\subsection{Sample Characterization}

The morphology of the catalyst was determined by field emission scanning electron microscopy (FESEM, JEOL JIB-4610F) and highresolution transmission electron microscopy (HR-TEM TECNAITM G2 Spirit Twin). The surface chemical composition was determined by energy-dispersive X-ray photoelectron spectroscopy (EDX). The chemical state of the copper, titanium and oxygen were determined using X-ray photoelectron spectroscopy (XPS Model ULVAC-PHI QUANTERA II). This model is equipped with $\mathrm{Al} \mathrm{Ka}$ as the monochromatic $\mathrm{X}$-ray source $(1486.6 \mathrm{eV})$ applied at $15 \mathrm{kV}$ and $50 \mathrm{~W}$, charge correction was performed at $\mathrm{C} 1 \mathrm{~s}$ by setting binding energies of $\mathrm{C}-\mathrm{C}$ to $284.8 \mathrm{eV}$, with a take-off angle of 45 degrees (the optimum angle for best detection capability of PHI QUANTERA II model), measurement area of $100 \mu \mathrm{m}$ (X-ray beam size). Wide scan analysis was performed using pass energy of 280 eV/step for determination of elemental composition while narrow scan energy analysis was performed throughout the binding energy range of interest at pass energy of $112 \mathrm{eV}$ with $0.1 \mathrm{eV} / \mathrm{step}$. Shirley method was used for spectrum background, with ratio of Gaussian and Lorentzian between 70:30 and 80:20. The crystallite form was observed using an X-ray diffractometer (XRD Shimadzu 7000 Maxima-X) with the scan rate at $2^{\circ}$ per minute, diffraction angle of $10-80^{\circ}$, and operated at $40 \mathrm{kV}$ and 30 $\mathrm{mA}, \mathrm{Cu}-\mathrm{Nia}$ radiation as the $\mathrm{X}$-ray source, and $\lambda=0.15406 \mathrm{~nm}$. The optical properties of photocatalyst were measured by UV-vis diffuse reflectance spectroscopy (UV-DRS by UV-vis Model Cary 60). The bandgap energy was calculated using the Kubelka-Munk method.

\subsection{Photocatalyst Performance Test}

Esterification and addition reaction were conducted in a laboratory photocatalytic reactor equipped with a pyrex-jacketed reactor, $250 \mathrm{~W}$ mercury lamp as a photon source, magnetic stirrer for mixing, external cooling water and an internal fan to keep the reaction occurred at ambient temperature. Kemiri sunan oil as much as 30 grams was esterified with a certain amount of methanol in the presence of a certain amount of $\mathrm{CuO} / \mathrm{TiO}_{2}$ photocatalyst. After the reaction was complete, the mixture formed two layers. The lower layer was composed of methyl ester produced from esterification, unreacted triglyceride, and solid catalyst, while the upper one was a mixture of methanol and water produced from the esterification. After the separation of the solid elements, the liquid mixture was dried at 120 ${ }^{\circ} \mathrm{C}$ for 3 hours to remove the remaining methanol and water formed during the reaction. The process was continued with a centrifugation process at a speed of $4500 \mathrm{rpm}$ in an hour to separate the esterified oil and remaining solid. The esterified oil was then checked for its FFA content by the titration of oil with strong alkali mixture $0.1 \mathrm{~N} \mathrm{NaOH}$ and its a-eleostearic acid composition by GC-MS (PerkinElmer Clarus SQ 8T). The diagrammatic scheme of this catalytic esterification and addition is described in Figure 1.

The FFA content was calculated using Equation (1) (SNI 01-3555-1998), referring to the IUPAC Standard Method for analysis of oils, fats, and derivatives.

$$
C_{F F A}=\frac{V \times T \times M}{10 \times m}
$$

where, $C_{F F A}$ is FFA content (\%), $V$ is the number of milliliter of standardized natrium hydroxide solution used, $T$ is the normality of the standardized natrium hydroxide solution used (0.1 N NaOH), $M$ is the molecular weight of fatty acid, and $m$ is the mass of oil in gram.

The FFA and $\alpha$-eleostearic acid conversion (Equations (2 and 3), respectively) was calculated by comparing the initial and the final FFA and $\alpha$-eleostearic acid contents in Kemiri Sunan oil.

$$
\begin{aligned}
& X_{F F A}(\%)=\frac{C_{F F A_{\text {initial }}}-C_{F F A_{\text {final }}}}{C_{F F A_{\text {intitial }}}} \times 100 \% \\
& X_{E A}(\%)=\frac{C_{E A_{\text {initial }}}-C_{E A_{\text {frnal }}}}{C_{E A_{\text {initial }}}} \times 100 \%
\end{aligned}
$$


where $X_{F F A}$ is FFA conversion, $C_{F F A \text { initial }}$ is FFA content of raw kemiri sunan oil, $C_{F F A}$ final is FFA content of Kemiri Sunan oil after esterification process. Whilst $X_{E A}$ is an a-eleostearic acid conversion with $C_{E A \text { initial }}$ is $\alpha$-eleostearic acid content in raw of Kemiri Sunan oil and $C_{A E \text { final }}$ is $\alpha$-eleostearic acid after addition reaction. In this study, the initial FFA content of raw material oil was $29.78 \%$ and the initial $\alpha$ eleostearic acid content was $40.81 \%$.

\section{Results and Discussion}

3.1 Physical and Chemical Characterizations of $\mathrm{CuO} / \mathrm{TiO}_{2}$ Photocatalyst

The surface morphology of $\mathrm{CuO} / \mathrm{TiO}_{2}$ appears through FESEM images, while the chemical composition can be seen through EDX. Figure 2 shows the surface morphology of $\mathrm{TiO}_{2}$ $\mathrm{P} 25$ and $\mathrm{CuO} / \mathrm{TiO}_{2}$. The surface morphology of $\mathrm{TiO}_{2} \mathrm{P} 25$ (Figure 2a) seem different with the

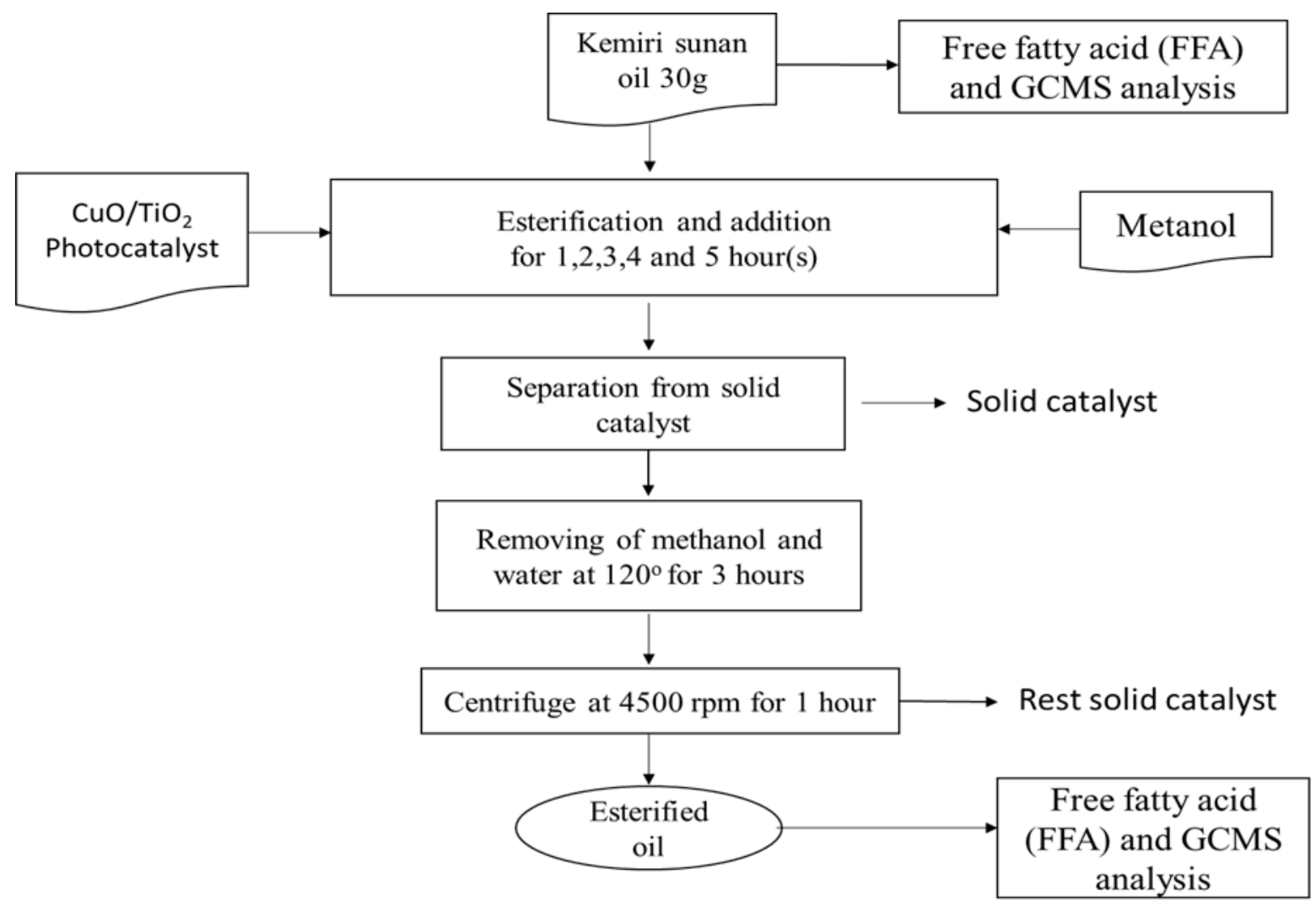

Figure 1. The schematic diagram of the catalytic esterification and addition reaction.
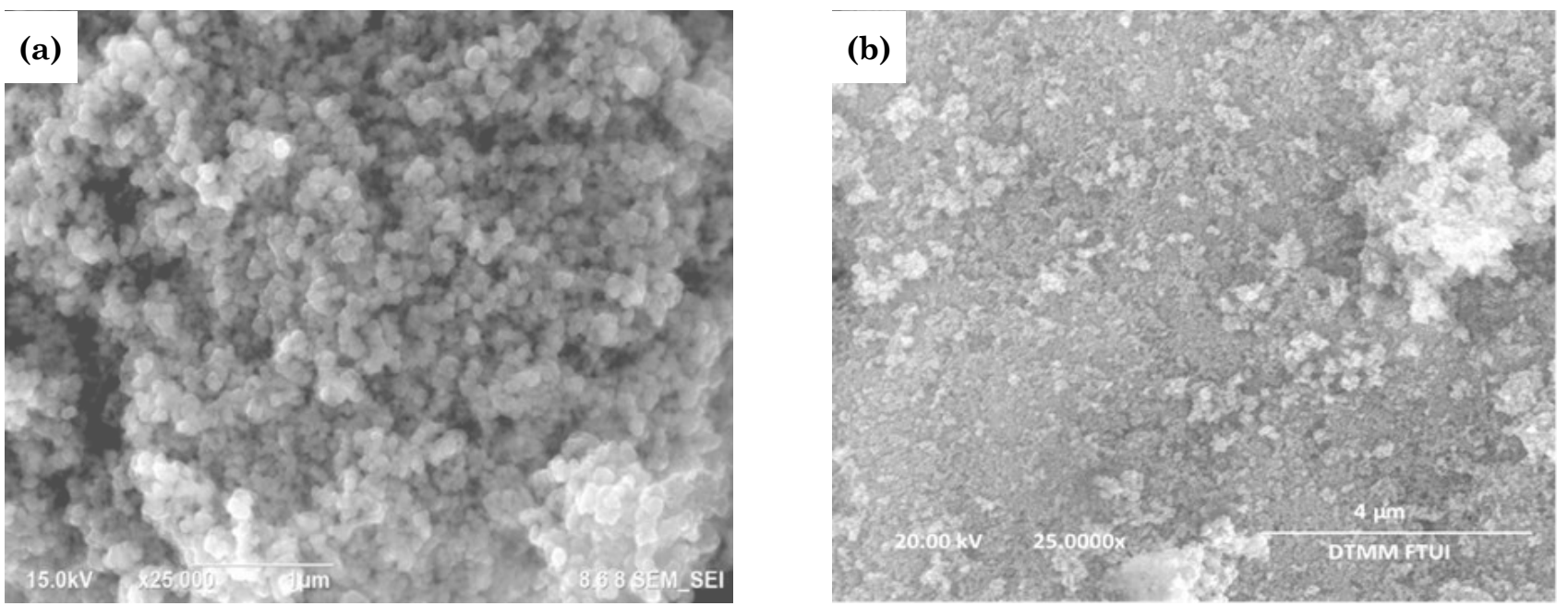

Figure 2. FESEM images of Photocatalysts (a) $\mathrm{TiO}_{2} \mathrm{P} 25$ and (b) $3 \% \mathrm{CuO} / \mathrm{TiO}_{2}$. 


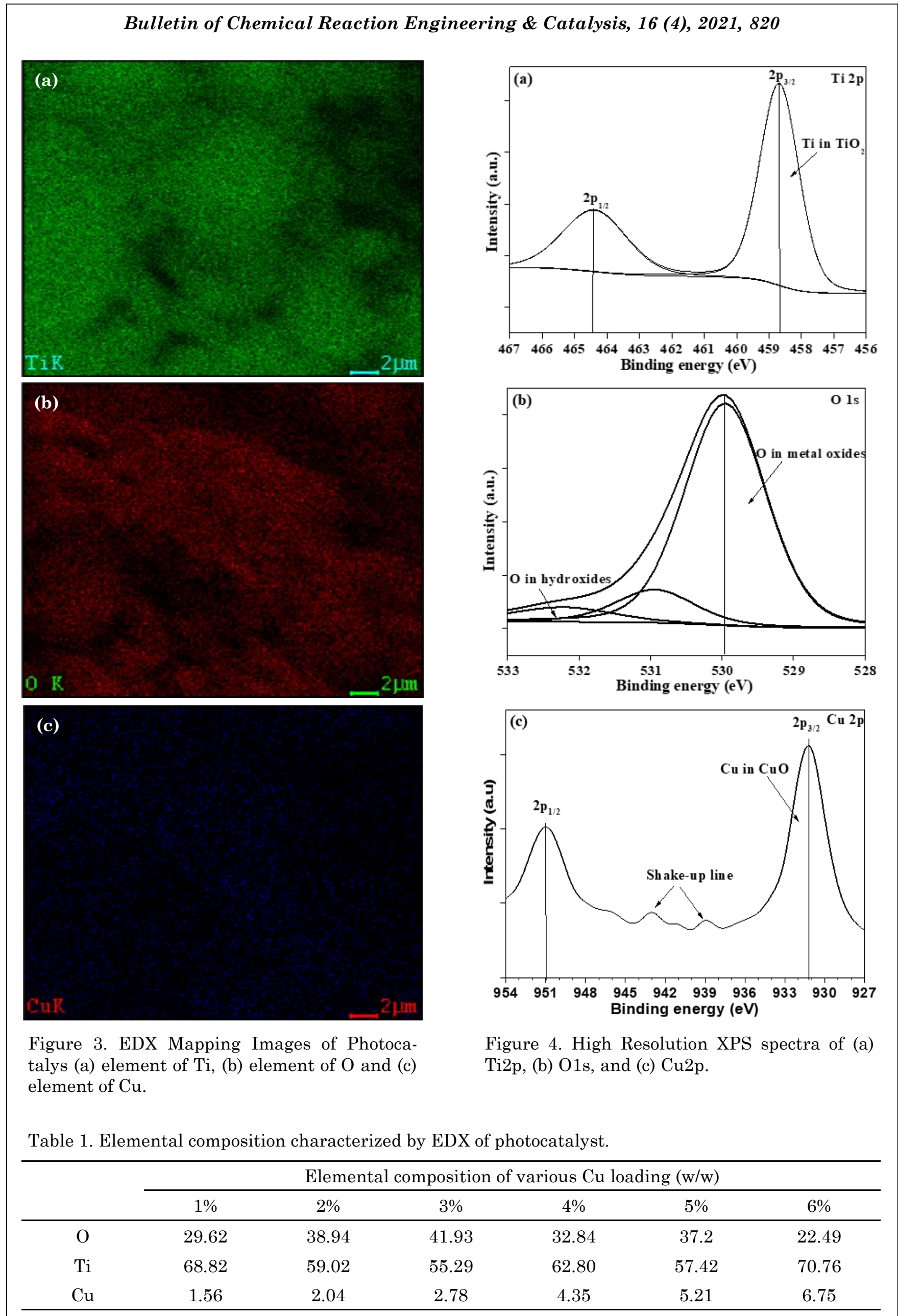


morphology of $3 \% \mathrm{CuO} / \mathrm{TiO}_{2}$ (Figure $2 \mathrm{~b}$ ). After adding $\mathrm{CuO}$, the $\mathrm{TiO}_{2}$ surface is slightly covered by $\mathrm{CuO}$ particles. It can be seen from the figure that $\mathrm{CuO}$ is dispersed well on the $\mathrm{TiO}_{2}$ surface. Figure 3 shows the EDX elemental mapping. This figure is evidence that $\mathrm{Ti}, \mathrm{Cu}$, and $\mathrm{O}$ were dispersed well on the surface of $\mathrm{TiO}_{2}$. This can also be seen by measuring the $\mathrm{CuO} / \mathrm{TiO}_{2}$ chemical composition, the results of which are shown in Table 1. The EDX result showed that the preparation of $\mathrm{CuO} / \mathrm{TiO}_{2}$ was successfully done. Highly heterogeneous dispersion of $\mathrm{CuO}$ on the $\mathrm{TiO}_{2}$ surface resulted in good interaction between $\mathrm{CuO}$ and $\mathrm{TiO}_{2}$ which enabled the transfer of charges. Hence, it resulted in the separation of charges and the reduction of recombination rate [24].

Furthermore, XPS determined the chemical state of copper in $\mathrm{CuO} / \mathrm{TiO}_{2}$ photocatalyst. The high resolution of the XPS spectrum of the $\mathrm{Cu}$ $2 p, O$ s and Ti $2 p$ region is showed in Figure 4. The photoelectron peak of Ti $2 p$ at binding energy of $458.7 \mathrm{eV}$ is attributed to $\mathrm{Ti}^{4+}$ in $\mathrm{TiO}_{2}$. The photoelectron peak of $\mathrm{O} 1 \mathrm{~s}$ is found at binding energy of $529.9 \mathrm{eV}$ that corresponds to the lattice oxygen in $\mathrm{TiO}_{2}$. This result is similar with previous study conducted by Nasralla et al. [30]. The measuring binding energies of $\mathrm{Cu}$ $\mathrm{p} 1 / 2$ and $\mathrm{Cu}$ p3/2 are 951 and $931.9 \mathrm{eV}$, respectively. These binding energies confirm that the oxidation state of $\mathrm{Cu}$ is $+2\left(\mathrm{Cu}^{2+}\right)$.

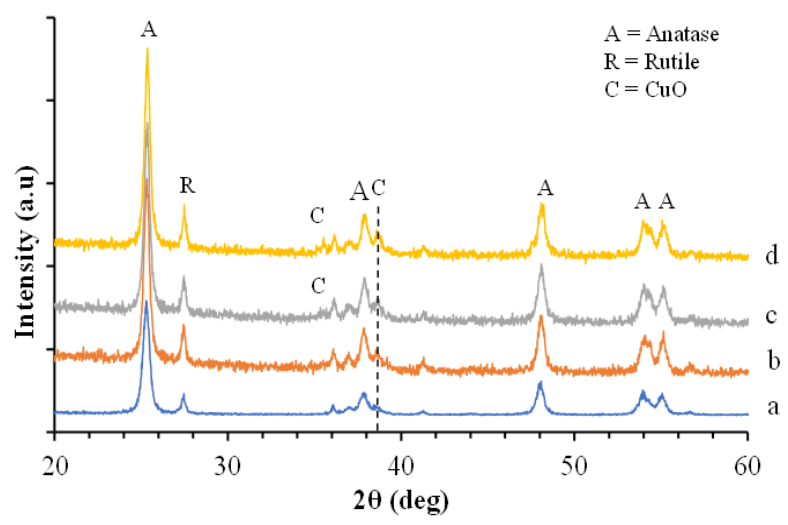

Figure 5. XRD patterns of the samplesTiO 2 P25 (a), $4 \% \mathrm{CuO} / \mathrm{TiO}_{2}$ (b), $5 \% \mathrm{CuTiO}_{2}$ (c), and $6 \%$ $\mathrm{CuO} / \mathrm{TiO}_{2}$ (d).
Whereas the peak at binding energy of 932.5 $\mathrm{eV}$ that implies $\mathrm{Cu}^{+}$in $\mathrm{Cu}_{2} \mathrm{O}$ is not found. In addition, the 'shake-up' line appeared at a binding energy of 938-944 eV also confirms the oxidation state of copper. This characteristic is only owned by $\mathrm{CuO}$. This result is similar to the previous study conducted by Yu et al. [27]. This is also in a good agreement with the XRD dan HRTEM characterization results which will be discussed further.

The powder XRD was used to identify the phase structure. The XRD pattern of standard $\mathrm{TiO}_{2} \mathrm{P} 25$ and $4 \%, 5 \%, 6 \% \mathrm{CuO}$ loadings on $\mathrm{TiO}_{2}$ can be seen in Figure 5. The diffractogram shows 3 main diffraction peaks at $2 \theta=$ $25.3^{\circ}, 37.9^{\circ}, 49^{\circ}$, and others peaks at $2 \theta=54.2^{\circ}$ and $55.4^{\circ}$ corresponding to anatase crystal form and at $2 \theta=27.5^{\circ}$ corresponding to the rutile phase. Compared to the diffractogram of $\mathrm{TiO}_{2} \mathrm{P} 25$, there are new weak peaks at near $2 \theta$ $=35.5^{\circ}$ and $38.6^{\circ}$ at $\mathrm{CuO}$ loadings of $4 \%, 5 \%$ and $6 \%$ corresponding to $\mathrm{CuO}$ peaks. This result is similar to the previous research conducted by Khemthong et al. [25] . The peaks are evidence that $\mathrm{Cu}$ was presented in the form of $\mathrm{CuO}\left(\mathrm{Cu}^{2+}\right)$ on that photocatalyst composite, not in the form of $\mathrm{Cu}\left(\mathrm{Cu}^{0}\right)$ or $\mathrm{Cu}_{2} \mathrm{O}\left(\mathrm{Cu}^{+1}\right)$. The existing $\mathrm{Cu}^{2+}$ could be explained because the calcination process was carried out in atmospheric conditions without reduction process. The weak peak of $\mathrm{CuO}$ was due to the high dispersion of $\mathrm{CuO}$ on the catalyst surface [24].

The average crystal size was calculated using Debye-Scherer formula, and the result is described in Table 2. The increase in $\mathrm{CuO}$ loadings did not significantly change the crystal size of $\mathrm{TiO}_{2}$, either in the anatase or rutile phases. This can be explained due to the low temperature of calcination $\left(300{ }^{\circ} \mathrm{C}, 2\right.$ hours) does not supplied enough energy to promote the $\mathrm{TiO}_{2}$ crystals growth and to put $\mathrm{CuO}$ into $\mathrm{TiO}_{2}$ lattice [27].

The morphology and microstructure of $\mathrm{CuO} / \mathrm{TiO}_{2}$ were studied using TEM and HRTEM. The TEM images in Figure 6a show that $\mathrm{CuO} / \mathrm{TiO}_{2}$ consists of nanoparticles sized 20-50 nm. The HRTEM images further corroborate the uniform distribution of $\mathrm{CuO}$ on the

Table 2. Effect of CuO loading on crystal size of $\mathrm{TiO}_{2}$.

\begin{tabular}{ccc}
\hline \multirow{2}{*}{$\mathrm{CuO}$ content $(\mathrm{wt} \%)$} & \multicolumn{2}{c}{ Crystal size $(\mathrm{nm})$} \\
\cline { 2 - 3 } & Anatase & Rutile \\
\hline 0 & 20,12 & 23.42 \\
4 & 20.41 & 27.59 \\
5 & 19.66 & 26.85 \\
6 & 20.75 & 27.31 \\
\hline
\end{tabular}


$\mathrm{TiO}_{2}$ surface. The $0.35 \mathrm{~nm}$ of lattice fringes is attributed to the d-spacing of $\mathrm{TiO}_{2}$, specifically anatase (101) crystal orientation. While the lattice fringers of $0.45 \mathrm{~nm}$ confirmed the presence of $\mathrm{CuO}$ nanoparticles as it was assigned to the
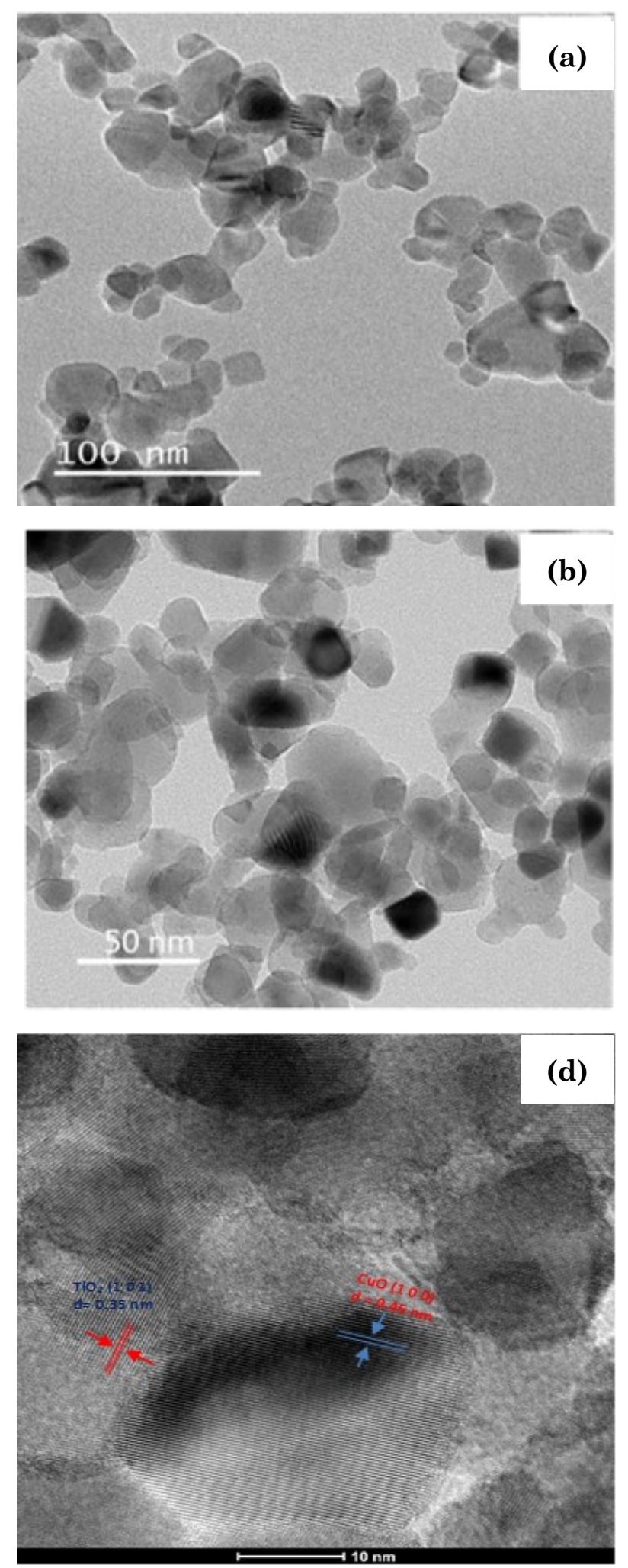

$d$-spacing of $\mathrm{CuO}$ nanoparticles (100) crystal plane.

The light absorption ability of the catalyst was observed with UV-DRS. The band gap energies of $\mathrm{CuO} / \mathrm{TiO}_{2}$ samples were determined with the Kubelka-Munk method [31]. The comparison of the band gap energies of $\mathrm{TiO}_{2}$ P25 and $\mathrm{CuO} / \mathrm{TiO}_{2}$ samples are described in Figure 7. Compared to $\mathrm{TiO}_{2}$ P25 bandgap energy, all of the samples of $\mathrm{CuO} / \mathrm{TiO}_{2}$ have lower bandgap energy. The bandgap energy values are described in the inset of the table. Reducing the bandgap energy will increase the visible light absorption which is much larger than UV light, so it will increase the performance of $\mathrm{TiO}_{2}$ as a photocatalyst.

3.2 FFA Photo-esterification and $\alpha$-Eleostearic Acid Photo-addition over $\mathrm{CuO} / \mathrm{TiO}_{2}$ Catalyst

The synthesized catalyst $\mathrm{CuO} / \mathrm{TiO}_{2}$ was then used to carry out the esterification and
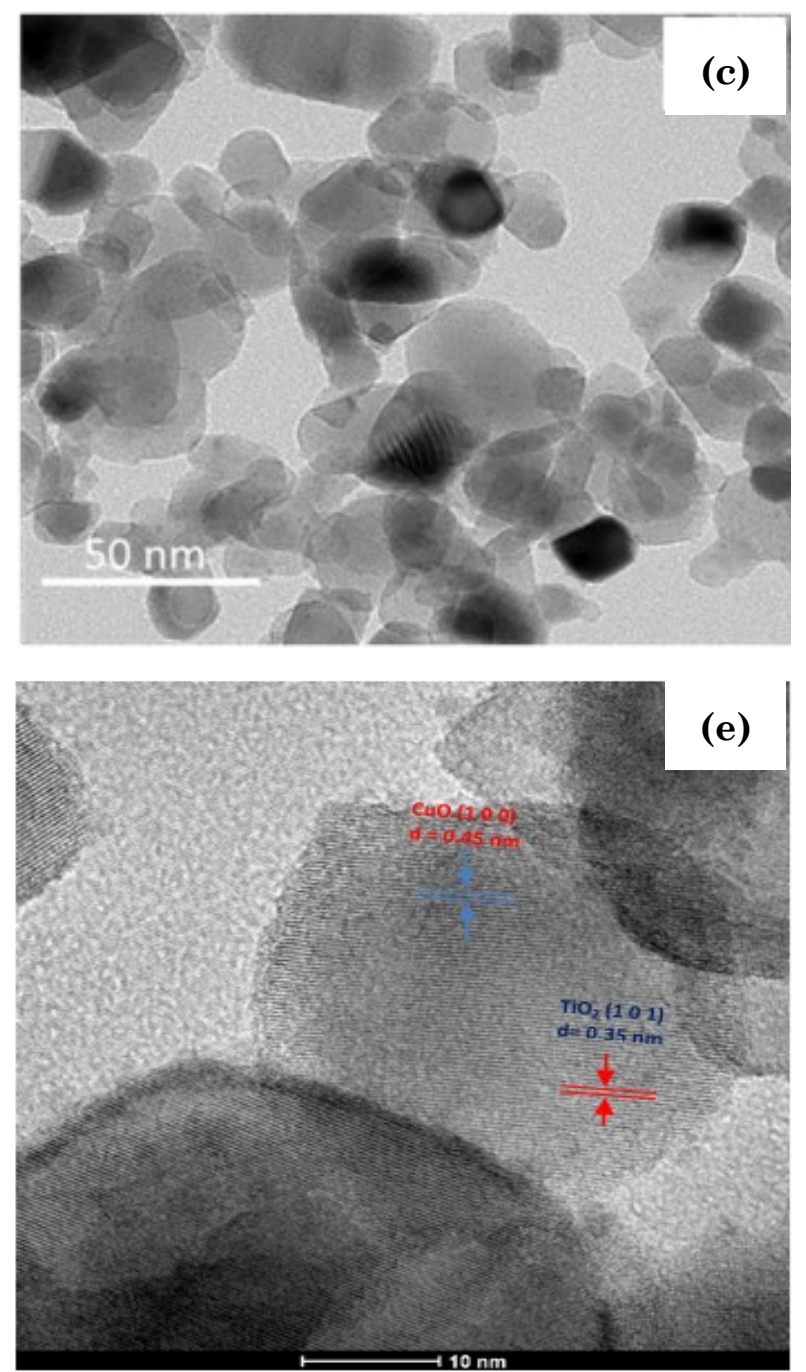

Figure 6. TEM images of $3 \% \mathrm{CuO} \mathrm{TiO}_{2}$ (a), $4 \% \mathrm{CuO} / \mathrm{TiO}_{2}$ (b), $5 \% \mathrm{CuO} / \mathrm{TiO}_{2}$ (c), HRTEM images of $4 \% \mathrm{CuO} / \mathrm{TiO}_{2}(\mathrm{~d})$ and $\mathrm{HRTEM}$ image of $6 \% \mathrm{CuO} / \mathrm{TiO}_{2}(\mathrm{e})$. 
addition of Kemiri Sunan oil. From the XRD diffractogram, the loading of $\mathrm{CuO}$ on $\mathrm{TiO}_{2}$ do not change the crystalline phase. The $\mathrm{TiO}_{2}$ crystal are still dominantly in anatase which is the most active phase in photocatalytic activity. Based on the EDX elemental mapping (Figure 3 ), XPS spectrum of $\mathrm{CuO}$ (Figure 4c), XRD pattern of $\mathrm{CuO}$ and TEM images showed the evidence of the dispersion of $\mathrm{CuO}$ on $\mathrm{TiO}_{2}$ surface. The presence of $\mathrm{CuO}$ increased the photocatalytic activity since $\mathrm{CuO}$ is an electrons donor [23] and is expected to increase the FFA and $\alpha$-eleostearic acid conversion.

The $\mathrm{CuO} / \mathrm{TiO}_{2}$ catalyst, when irradiated by photons, generates electrons and holes which drives esterification with the mechanism proposed by Corro $[17,18]$. Electrons generated by photocatalyst react with fatty acid adsorbed at the catalyst surface and at the same time holes is reacted with methanol adsorbed on the catalyst surface to form $\mathrm{CHO}$ radicals $\left(\mathrm{CH}_{3} \mathrm{O} \cdot\right)$ that will react to form methyl ester and water.

The GC-MS characterization results of the Kemiri Sunan oil and one sample of esterified Kemiri Sunan oil are shown in Table 3. Initially, the Kemiri Sunan oil contained the most of $\alpha$-eleostearic acid (41.8\%). After reaction, the $\alpha$-eleostearic acid is reduced/over, and the amount of linoleic acid, oleic acid, stearic acid and palmitic acid were increased.

The results indicate that during the reaction, besides esterification, the addition reaction also occurred. Based on the ability of $\mathrm{CuO} / \mathrm{TiO}_{2}$ to encourage hydrogen formation from water, it is not surprising that the addition reaction can occur simultaneously with esterification. The hydrogen formed from water photo-splitting attacks the double bonds contained in $\alpha$-eleostearic acid to form linoleic acid, oleic acid, or stearic acid. The effect of sev-

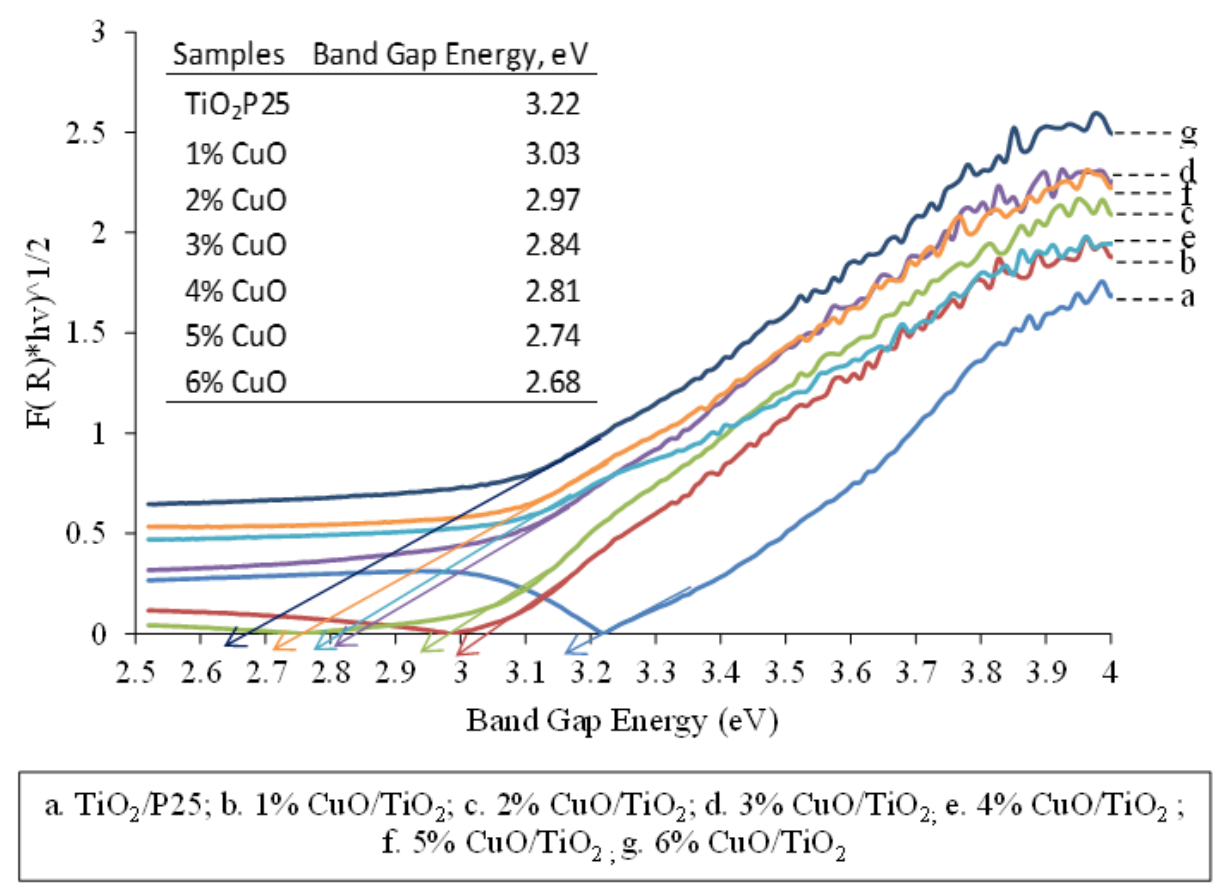

Figure 7. The Band gap energy of $\mathrm{TiO}_{2} \mathrm{P} 25$ and $\mathrm{CuO} / \mathrm{TiO}_{2}$ samples.

Table 3. GCMS result of Kemiri Sunan oil and esterified kemiri sunan oil*)

\begin{tabular}{lccc}
\hline Fatty Acid compound & Chemical Formula & $\begin{array}{c}\text { Composition in kemiri } \\
\text { sunan oil }(\% \mathrm{~m} / \mathrm{m})\end{array}$ & $\begin{array}{c}\text { Composition in esterified } \\
\text { kemiri sunan oil }(\% \mathrm{~m} / \mathrm{m})\end{array}$ \\
\hline Palmitic acid & $\mathrm{C}_{16} \mathrm{H}_{32} \mathrm{O}_{2}$ & 13.62 & 39.62 \\
Stearic acid & $\mathrm{C}_{18} \mathrm{H}_{36} \mathrm{O}_{2}$ & 4.9 & 11.62 \\
Oleic acid & $\mathrm{C}_{18} \mathrm{H}_{34} \mathrm{O}_{2}$ & 14.18 & 30.53 \\
Linoleic acid & $\mathrm{C}_{18} \mathrm{H}_{32} \mathrm{O}_{2}$ & 16.9 & 16.74 \\
$\alpha$-Eleostearic acid & $\mathrm{C}_{18} \mathrm{H}_{30} \mathrm{O}_{2}$ & 41.8 & 0 \\
Others & & 8.6 & 1.49 \\
\hline
\end{tabular}

*)After esterification 4 hours with 5\% amount of catalyst, 30:1 methanol :oil molar ratio, $4 \% \mathrm{CuO} / \mathrm{TiO}_{2}$. 
eral variables to FFA and $\alpha$-eleostearic acid were further discussed.

\subsection{Effect of $\mathrm{CuO}$ Lading on $\mathrm{TiO}_{2}$}

The $\mathrm{CuO}$ amount in $\mathrm{TiO}_{2}$ has a critical effect on photocatalyst activity. The $\mathrm{CuO}$ loading significantly reduces FFA in esterification, as shown in Figure 9. At $\mathrm{CuO}$ content $=0$, the conversion of FFA and $\alpha$-eleostearic acid becomes low, because of the rapid recombination between electrons and holes in pure $\mathrm{TiO}_{2}$. The interaction between $\mathrm{CuO}$ and $\mathrm{TiO}_{2}$ in photocatalytic activity was described in Figure 8.

Semiconductor $\mathrm{CuO}$ is more cathodic than $\mathrm{TiO}_{2}$ (the conduction bands of $\mathrm{TiO}_{2}$ and $\mathrm{CuO}$ are $-4 \mathrm{eV}$ and $-0.8 \mathrm{eV}$, respectively). When exposed to photons, the $\mathrm{CuO}$ generates electrons and donate those electrons to $\mathrm{TiO}_{2}$ that collects on its surface. Meanwhile, valence band of
$\mathrm{TiO}_{2}$ is more positive than $\mathrm{CuO}\left(\mathrm{TiO}_{2}=+2.8\right.$ $\mathrm{eV}$, while $\mathrm{CuO}=+0.9 \mathrm{eV}$ ), allowing the holes formed by $\mathrm{TiO}_{2}$ to collect at the $\mathrm{CuO}$ surface [23]. This charge separation reduces the recombination rate and increase the residence time of electrons and holes in the system. Furthermore, based on the UV-DRS results, the band gap energy of all samples decreased with the increment of $\mathrm{CuO}$ loading. Reducing the band gap energy increases the visible light absorption. In addition, narrower band gap energy speeds up the electron transfer from valence band into conduction band and enhance the photocatalytic activity. The generated electrons and holes promote the esterification of fatty acid and the addition of $\alpha$-eleostearic acid.

In the addition reaction step, after $2 \% \mathrm{CuO}$ loading, almost all of $\alpha$-eleostearic acid were converted, but increasing $\mathrm{CuO}$ amount still

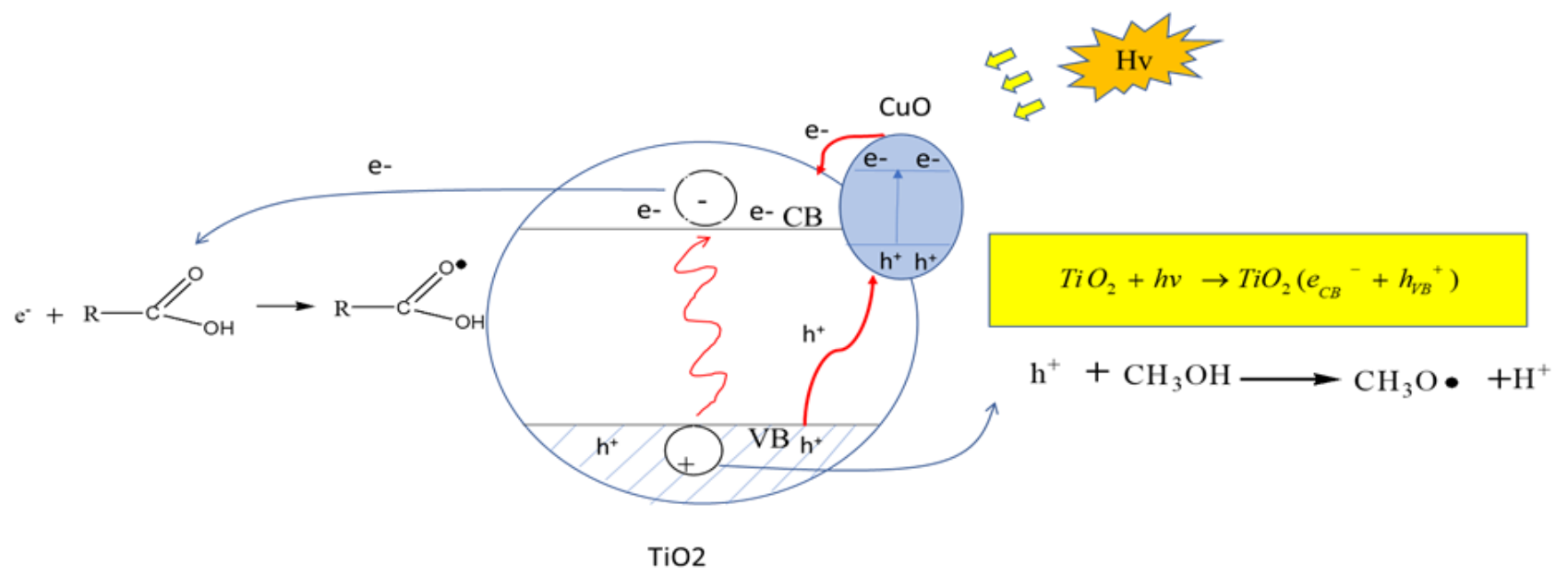

Figure 8. Schematic diagram of charge transfer of $\mathrm{CuO} / \mathrm{TiO}_{2}$ photocatalyst under irradiation.

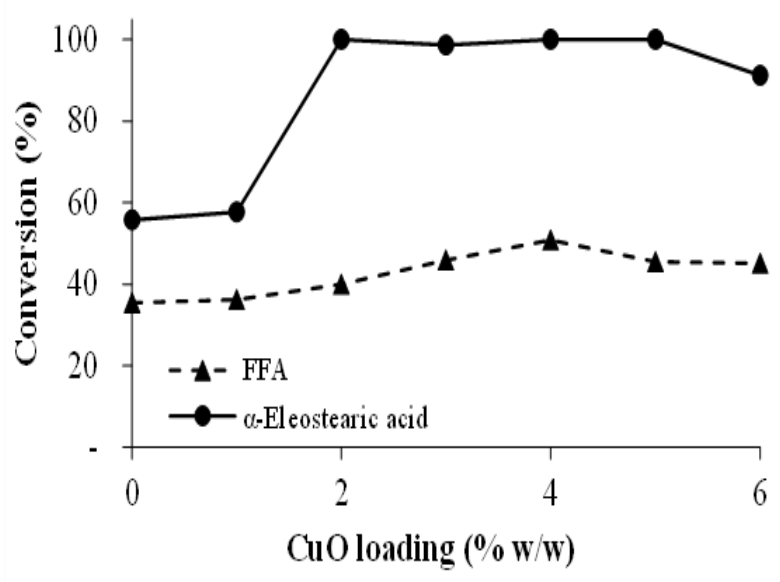

Figure 9. The effect of $\mathrm{CuO}$ loading into $\mathrm{TiO}_{2}$ $(\% \mathrm{w} / \mathrm{w})$ to FFA and $\alpha$-Eleostearic acid conversion (4 hour reaction time, $5 \%$ catalyst amount, $1: 12$ of oil : methanol molar ratio).

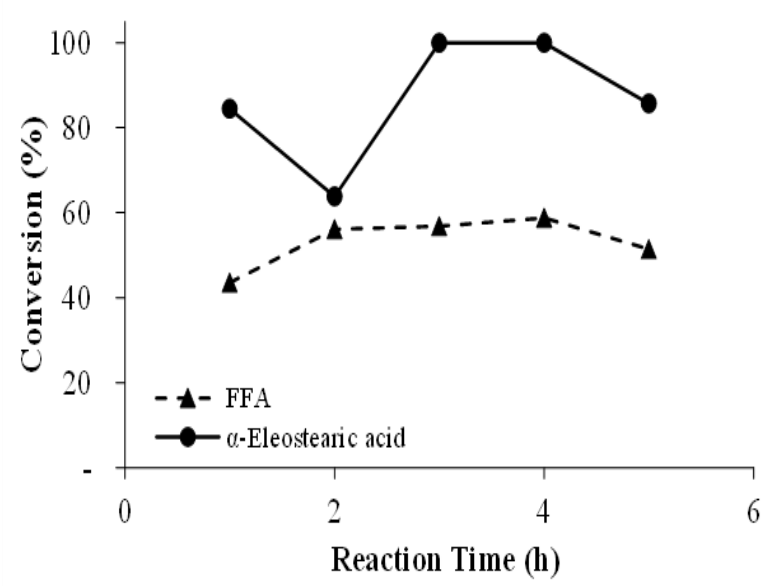

Figure 10. The effect of reaction time to FFA and $\alpha$-Eleostearic acid conversion $(4 \%$ w/w $\mathrm{CuO} / \mathrm{TiO}_{2}, 5 \%$ catalyst concentration, $1: 30$ of oil: methanol molar ratio). 
played a role in reducing FFA content. In this study, the best $\mathrm{CuO}$ content to $\mathrm{TiO}_{2}$ was $4 \%$ $(\mathrm{w} / \mathrm{w})$. It can be explained that increasing $\mathrm{CuO}$ loading by more than $4 \%$ causes the formation of agglomerates on the $\mathrm{TiO}_{2}$ surface which makes a shading effect and might act as recombination center that result in decreasing photocatalytic activity.

\subsection{Effect of Reaction Time}

The effect of reaction time on the FFA and $\alpha$-eleostearic acid conversion is showed in Figure 10. Reaction time affects the duration of contact between reactants and irradiation time. The lowest FFA content was obtained at a 4 hour reaction time. Almost all of the $\alpha$-eleostearic acid was converted into a lower double bond after 3 hours reaction, but esterification still running until 4 hours. After 4 hours, the FFA slightly decreased due to the saturated reaction.

\subsection{Effect of Catalyst Amount}

The effect of catalyst amount on reducing FFA is showed in Figure 11. The reaction occurred on the catalyst surface. Hence, the more catalyst, the larger the surface area and the more the FFA converted. When the concentration of catalyst exceeds $5 \%$, the reduction of FFA gets lower. It makes sense; the more the catalyst added avoids its nanoparticles being irradiated by the UV light (shading effect).

\subsection{Effect of Oil:Methanol Molar Ratio}

The effect of the ratio of oil to methanol on the FFA reduction is shown in Figure 12. Stoichiometrically, $1 \mathrm{~mol}$ of FFA needs $1 \mathrm{~mol}$ of

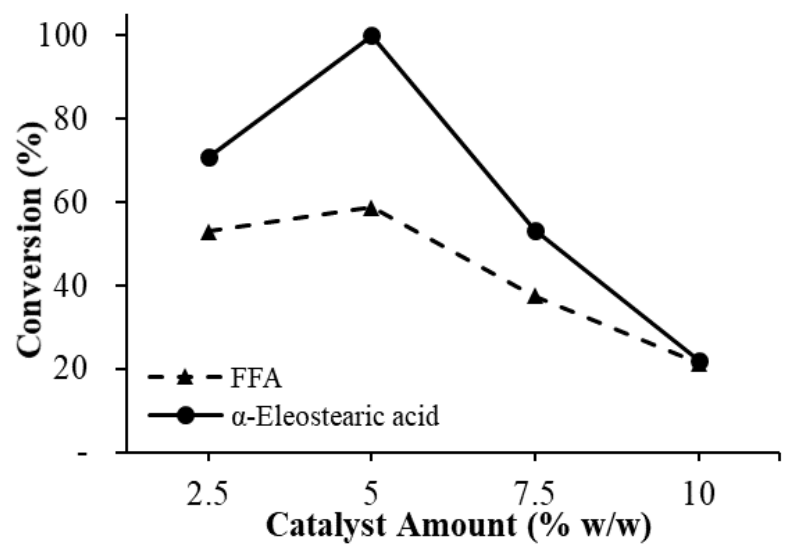

Figure 11. Effect of catalyst amount to FFA and $\alpha$-eleostearic acid conversion (4 hours reaction time, $4 \% \mathrm{CuO} / \mathrm{TiO}_{2}, 1: 30$ of oil:methanol molar ratio). methanol to produce $1 \mathrm{~mol}$ of methyl ester. More methanol drives the reaction towards the desired product, meaning decreasing the FFA content. Using high molar ratio of oil:methanol of 1:30 slightly decreases, compared to using that of 1:20, but using 1:40 makes the FFA content slightly increases. Increasing the methanol ratio increases liquid volume in the reactor and make the UV irradiation less effective in activating the catalyst surface or the reaction has been saturated. The phenomenon of the high molar ratio of methanol was also found in acid esterification. Al-Sakkari et al. [16] reported the use of 52:1 methanol to oil molar ratio in esterification process of waste cooking oil using sulfuric acid catalyst.

The results presented in this study showed that $\mathrm{CuO} / \mathrm{TiO}_{2}$ can convert FFA and $\alpha$-eleostearic acid simultaneously. Compared to acid esterification that frequently used, the process presented in this study can reduce energy consumption, excess methanol, and costly stainless steel and also can convert unsaturated FFA. The best operating condition was obtained at 4 hours reaction time with catalyst amount of $5 \%(\mathrm{w} / \mathrm{w}), \mathrm{CuO}$ loading of $5 \%(\mathrm{w} / \mathrm{w})$, and oil to methanol molar ratio of 1:30, resulting in a final FFA of $12.28 \%$ with a conversion of $58.74 \%$. The product was still containing high enough FFA content. The photocatalyst selectivity might be low to convert the FFA from natural materials that contain many compounds. At the same condition, the conversion of $\alpha$-eleostearic acid was $100 \%$. Under these conditions, the fatty acid compositions were obtained as follows: palmitic acid $39.62 \%$, stearic acid $11.62 \%$, oleic acid $30.52 \%$, and linoleic acid $16.74 \%$.

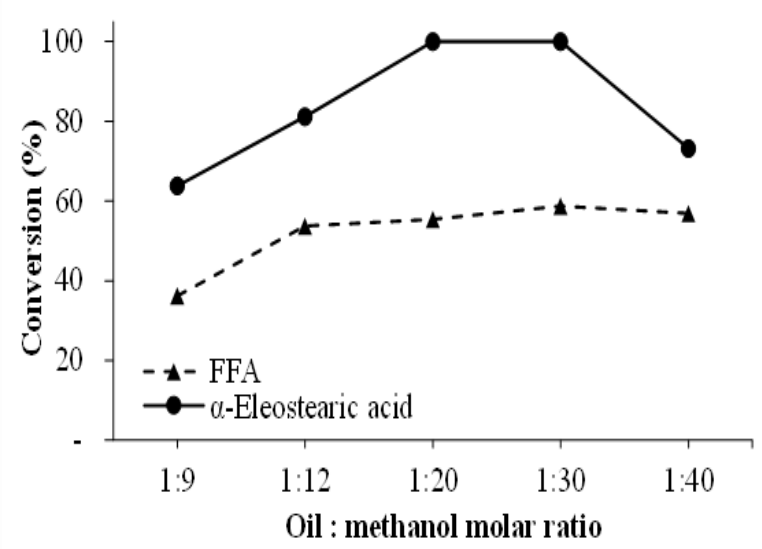

Figure 12. The effect of oil:methanol molar ratio (4 hours reaction time, $5 \% \mathrm{CuO} / \mathrm{TiO}_{2}$, loading catalyst $5 \% \mathrm{w} / \mathrm{w}$ ) to FFA and $\alpha$-eleostearic acid. 


\subsection{Proposed Esterification and Addition Reac-} tion Mechanism

The first step of photocatalytic esterification is the diffusion of methanol $\left(\mathrm{CH}_{3} \mathrm{OH}\right)$ and FFA (R-COOH) to the $\mathrm{CuO} / \mathrm{TiO}_{2}$ surface, followed by the adsorption of methanol and FFA on the photocatalyst surface. When $\mathrm{TiO}_{2}$ is exposed to the light, electrons from the valence band are excited to the conduction band and left the holes $\left(h^{+}\right)$(step 1). In the esterification step, $\mathrm{R}-\mathrm{COOH}$ adsorbed on the photocatalyst surface is reduced by electrons $\left(e^{-}\right)$to form superoxide species $\left(\mathrm{RCO}^{-}\right) \mathrm{OH}$ (step 2). At the same time, the holes react with $\mathrm{CH}_{3} \mathrm{OH}$ adsorbed on the photocatalyst surface, producing $\mathrm{CH}_{3} \mathrm{O}$ - radicals and hydrogen ions $\left(\mathrm{H}^{+}\right)$(step 3$)$. The generated $\mathrm{CH}_{3} \mathrm{O} \cdot$ radicals, $\mathrm{H}^{+}$, and $\left(\mathrm{RCO}^{-}\right) \mathrm{OH}$ subsequently react to produce the intermediates and final esterification products, namely methyl esters and water (steps 4, 5, 6). In the addition step, the holes oxidize water molecules to produce oxygen molecules and hydrogen ions $\left(\mathrm{H}^{+}\right)$ (step 7). Furthermore, hydrogen ions reduce electrons to produce hydrogen free radicals on the catalyst surface (step 8). Two hydrogen free radicals react to form hydrogen (step 9). The $\alpha$-eleostearic acid, which is also on the catalyst surface, is attacked by hydrogen free radical to form linoleic acid free radicals (step 10). Furthermore, linoleic acid free radical attacks hydrogen $\left(\mathrm{H}_{2}\right)$ to form linoleic acid and hydrogen free radical (step 11). Analog to the first double bond breaking, the presence hydrogen free radicals trigger the breaking of the second double bond to form oleic acid or the third double bond to form stearic acid (step 12). The detailed schematics of esterification and addition reaction mechanism are described in Figures 13 and 14. After producing water from esterification, the addition reaction begins with those prediction mechanisms, as described in Figure 14.

\section{Conclusions}

A photocatalytic process using $\mathrm{CuO} / \mathrm{TiO}_{2}$ catalyst can perform simultaneous esterification and addition reaction of the FFA in kemiri sunan to obtained the reaction product of less the FFA content and nearly zero number of poly-unsaturated fatty acid. Characterization results of the $\mathrm{CuO} / \mathrm{TiO}_{2}$ catalyst by FESEM images and HRTEM images showed the evidence that $\mathrm{CuO}$ was highly dispersed on the $\mathrm{TiO}_{2}$ surface. The EDX elemental mapping and measuring the $\mathrm{CuO} / \mathrm{TiO}_{2}$ chemical composition also give evidence that $\mathrm{CuO}$ were dispersed well on the surface of $\mathrm{TiO}_{2}$. Whilst the XPS spectrum showed that copper was in the state of $\mathrm{Cu}^{2+}$ $(\mathrm{CuO})$ and titanium is in $\mathrm{Ti}^{4+}\left(\mathrm{TiO}_{2}\right)$. Moreover, the XRD diffractogram showed the crystalline forms of $\mathrm{TiO}_{2}$ were still dominantly in the form of anatase. Modifying $\mathrm{TiO}_{2}$ with $\mathrm{CuO}$ significantly reduced the band gap energy and enhanced its photocatalytic activity. It was found that the $\mathrm{CuO} / \mathrm{TiO}_{2}$ photocatalyst was able to convert FFA by esterification reaction and $\alpha$-eleostearic acid by addition reaction more effectively than that of $\mathrm{TiO}_{2} \mathrm{P} 25$. The optimum operation condition was obtained at 4 hours, $5 \%(\mathrm{w} / \mathrm{w})$ catalyst concentration, 4\% (w/w) $\mathrm{CuO}$ loading, and 1:30 oil:methanol molar ratio. At the condition, the final FFA content is $12.28 \%$ with the conversion was around $59 \%$ and the $\alpha$-eleostearic acid (C18:3) conversion was $100 \%$. The photocatalyst selectivity is relatively low on the reduction of the FFA by esterification, but it very high on the reduction of the $\alpha$-eleostearic acid. The reaction product with low content of $\alpha$-eleostearic acid which is a multiple double bond, is expected to have better oxidation stability.

\section{Acknowledgements}

This work is financially supported by Hibah Penelitian Disertasi Doktor (PDD) 2019 funded by DRPM Ministry of Education, Culture, Research, and Technology of the Republic of Indonesia.

\section{References}

[1] Holilah, H., Prasetyoko, D., Oetami, T.P., Santosa, E.B., Zein, Y.M., Bahruji, H., Fansuri, H., Ediati, R., Juwari, J. (2015).The potential of Reutealis trisperma seed as a new nonedible source for biodiesel production. Biomass Conversion and Biorefinery, 5(4), 347353. DOI: $10.1007 / \mathrm{s} 13399-014-0150-6$

[2] Kumar, K.R., Chandrika, K., Prasanna, K., Gowda, B. (2015). Biodiesel production and characterization from non-edible oil tree species Aleurites trisperma Blanco. Biomass Conversion and Biorefinery, 5(3), 287-294. DOI: $10.1007 / \mathrm{s} 13399-014-0152-4$

[3] Jin, Y., Tian, S., Guo, J., Ren, X., Li, X., Gao, S. (2016). Synthesis, characterization and exploratory application of anionic surfactant fatty acid methyl ester sulfonate from waste cooking oil. Journal of Surfactants and Detergents, 19(3), 467-475. DOI: 10.1007/s11743016-1813-z

[4] Demirbas, A. (2009). Progress and recent trends in biodiesel fuels. Energy Conversion and Management, 50(1), 14-34. DOI: 10.1016/j.enconman.2008.09.001 


$$
\mathrm{TiO}_{2}+\mathrm{hv} \longrightarrow \mathrm{TiO}_{2}\left(\mathrm{e}^{-}+\mathrm{h}^{+}\right)
$$<smiles>[R]C(=O)O[Na]</smiles>

$$
\mathrm{h}^{+}+\mathrm{CH}_{3} \mathrm{OH} \longrightarrow \mathrm{CH}_{3} \mathrm{O} \bullet+\mathrm{H}^{+} \text {. }
$$
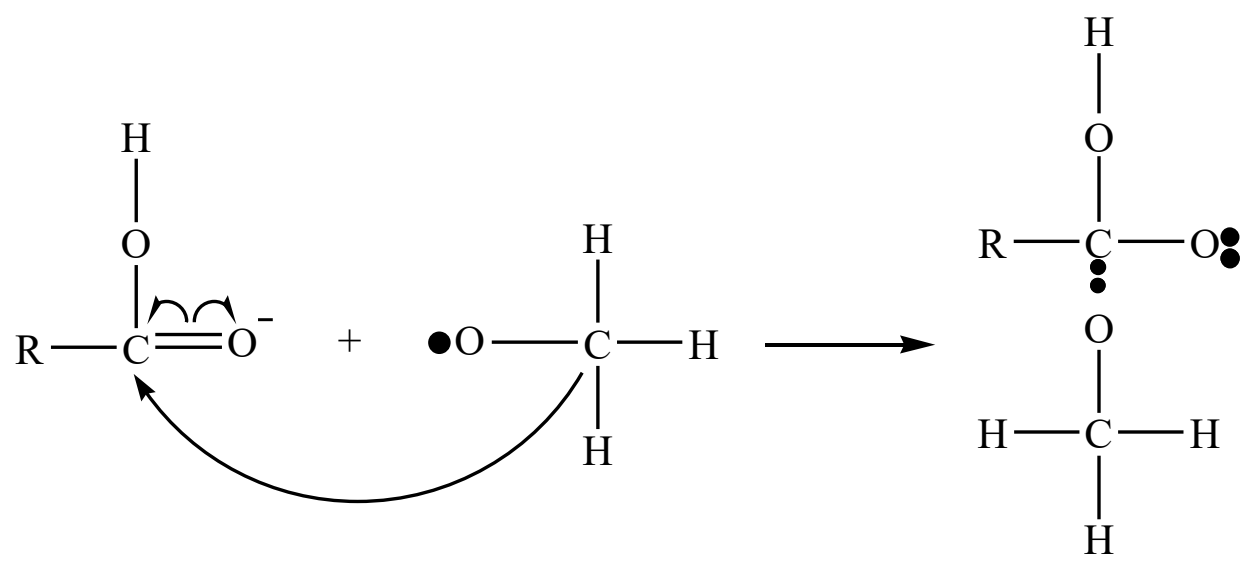<smiles>[R]C([2H])(O[CH])O[CH]</smiles><smiles>[R]C([R])(O[2H])O[2H]</smiles><smiles>[R]C12CCCCC([R])(O[IH]C1)O[Tl]CCC2</smiles><smiles>[R]C(=O)OC</smiles>

Figure 13. The schematics of esterification reaction mechanism. 


$$
\begin{aligned}
\mathrm{H}_{2} \mathrm{O}+2 \mathrm{~h}_{\mathrm{VB}}^{+} & \longrightarrow 0.5 \mathrm{O}_{2}+2 \mathrm{H}^{+} \\
\mathrm{H}^{+}+\mathrm{e}^{-} & \longrightarrow \bullet \mathrm{H} \\
\bullet \mathrm{H}+\bullet \mathrm{H} & \longrightarrow \mathrm{H}_{2}
\end{aligned}
$$

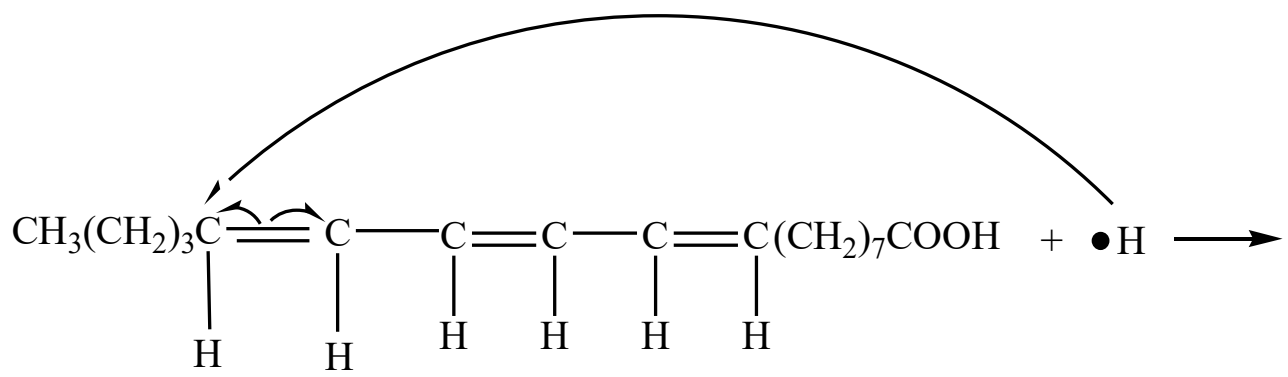<smiles>CCCCCC=CC=CCCC(=O)O</smiles>

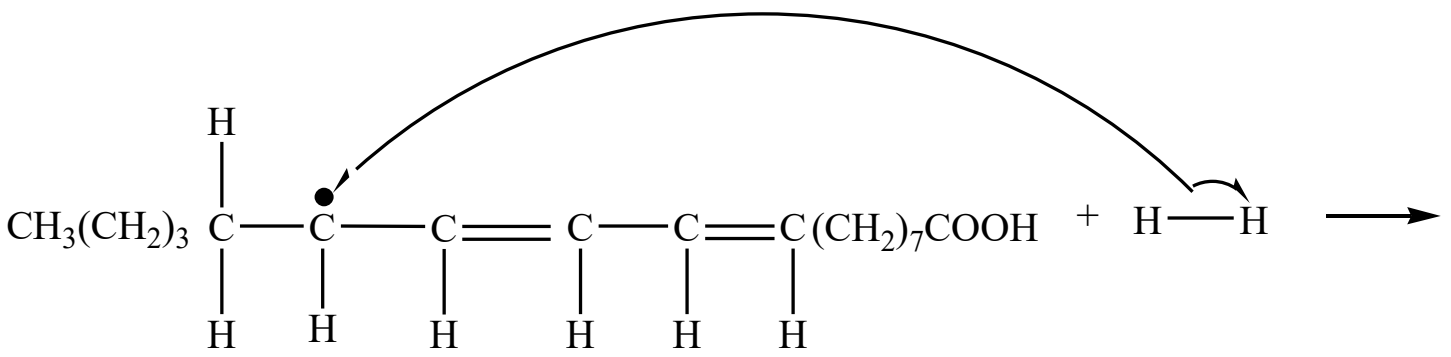<smiles>CCCCCC=CCCC(=O)O</smiles>

analog to the breaking double bond mechanism by hydrogen free radicals appears in step (10) and (11), the producing stearic acid in shown in step (12)

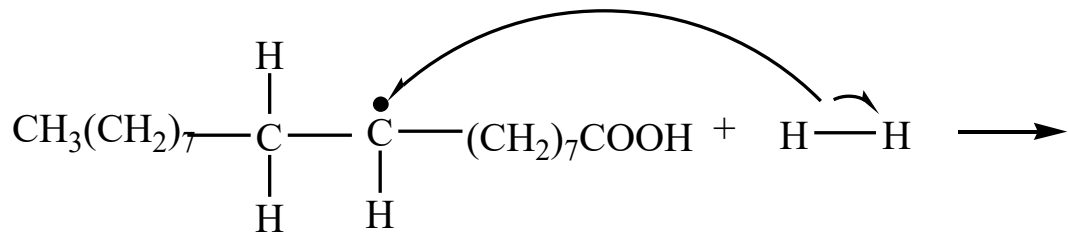

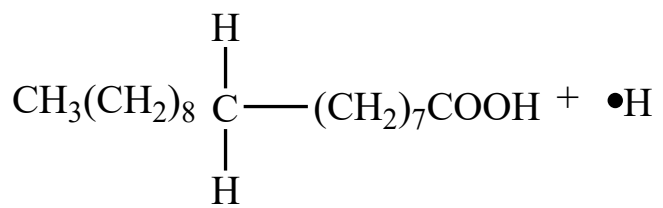

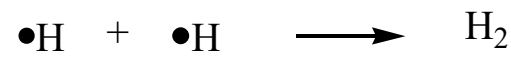

Figure 14. The schematics of addition reaction mechanism. 
[5] Manique, M.C., Silva, A.P., Alves, A.K., Bergmann, C.P. (2016). Application of hydrothermally produced $\mathrm{TiO}_{2}$ nanotubes in photocatalytic esterification of oleic acid. Materials Science and Engineering: B, 206, 17-21. DOI: 10.1016/j.mseb.2016.01.001

[6] Canakci, M., Van Gerpen, J. (2001). Biodiesel production from oils and fats with high free fatty acids. Transactions of the ASAE, 44(6), 1429. DOI: $10.13031 / 2013.7010$

[7] Dorado, M.P., Ballesteros, E., López, F.J., Mittelbach, M. (2004). Optimization of alkalicatalyzed transesterification of Brassica C arinata oil for biodiesel production. Energy \& Fuels, 18(1), 77-83. DOI: 10.1021/ef0340110

[8] Dupont, J., Suarez, P.A., Meneghetti, M.R., Meneghetti, S.M. (2009). Catalytic production of biodiesel and diesel-like hydrocarbons from triglycerides. Energy \& Environmental Science, 2(12), 1258-1265. DOI: 10.1039/B910806H

[9] Vyas, A.P., Verma, J.L., Subrahmanyam, N. (2010). A review on FAME production processes. Fuel, 89(1), 1-9. DOI: 10.1016/j.fuel.2009.08.014

[10] Martín, C., Moure, A., Martín, G., Carrillo, E., Domínguez, H., Parajo, J.C. (2010). Fractional characterisation of jatropha, neem, moringa, trisperma, castor and candlenut seeds as potential feedstocks for biodiesel production in Cuba. Biomass and Bioenergy, 34(4), 533538. DOI: $10.1016 /$ j.biombioe.2009.12.019

[11] Silitonga, A., Mahlia, T., Kusumo, F., Dharma, S., Sebayang, A., Sembiring, R., Shamsuddin, A. (2019). Intensification of Reutealis trisperma biodiesel production using infrared radiation: Simulation, optimisation and validation. Renewable Energy, 133, 520527. DOI: 10.1016/j.renene.2018.10.023

[12] Silitonga, A.S., Mahlia, T.M.I., Ong, H.C., Riayatsyah, T.M.I., Kusumo, F., Ibrahim, H., Dharma, S., Gumilang, D. (2017). A comparative study of biodiesel production methods for Reutealis trisperma biodiesel. Energy Sources, Part A: Recovery, Utilization, and Environmental Effects, 39(20), 2006-2014. DOI: 10.1080/15567036.2017.1399174

[13] Chuah, L.F., Klemeš, J.J., Yusup, S., Bokhari, A., Akbar, M.M. (2017). A review of cleaner intensification technologies in biodiesel production. Journal of Cleaner Production, 146, 181-193. DOI: 10.1016/j.jclepro.2016.05.017

[14] Zhang, Y., Dube, M., McLean, D., Kates, M. (2003). Biodiesel production from waste cooking oil: 1. Process design and technological assessment. Bioresource Technology, 89(1), 116. DOI: 10.1016/S0960-8524(03)00040-3
[15] Marchetti, J., Errazu, A. (2008). Esterification of free fatty acids using sulfuric acid as catalyst in the presence of triglycerides. Biomass and Bioenergy, 32(9), 892-895. DOI: 10.1016/j.biombioe.2008.01.001

[16] Al-Sakkari, E.G., Abdeldayem, O.M., ElSheltawy, S., Abadir, M.F., Soliman, A., Rene, E.R., Ismail, I. (2020). Esterification of high FFA content waste cooking oil through different techniques including the utilization of cement kiln dust as a heterogeneous catalyst: A comparative study. Fuel, 279, 118519. DOI: 10.1016/j.fuel.2020.118519

[17] Corro, G., Pal, U., Tellez, N. (2013). Biodiesel production from Jatropha curcas crude oil using $\mathrm{ZnO} / \mathrm{SiO}_{2}$ photocatalyst for free fatty acids esterification. Applied Catalysis B: Environmental, $129, \quad 39-47$. DOI: 10.1016/j.apcatb.2012.09.004

[18] Corro, G., Sánchez, N., Pal, U., Cebada, S., Fierro, J.L.G. (2017). Solar-irradiation driven biodiesel production using $\mathrm{Cr} / \mathrm{SiO} 2$ photocatalyst exploiting cooperative interaction between $\mathrm{Cr}^{6+}$ and $\mathrm{Cr}^{3+}$ moieties. Applied Catalysis B: Environmental, 203, 43-52. DOI: 10.1016/j.apcatb.2016.10.005

[19] Verma, P., Kaur, K., Wanchoo, R.K., Toor, A.P. (2017). Esterification of acetic acid to methyl acetate using activated $\mathrm{TiO}_{2}$ under UV light irradiation at ambient temperature. Journal of Photochemistry and Photobiology A: Chemistry, 336, 170-175. DOI: 10.1016/j.jphotochem.2016.11.021

[20] Schneider, J., Matsuoka, M., Takeuchi, M., Zhang, J., Horiuchi, Y., Anpo, M., Bahnemann, D.W. (2014). Understanding TiO2 photocatalysis: mechanisms and materials. Chemical Reviews, 114(19), 9919-9986. DOI: 10.1021/cr5001892

[21] Ohtani, B. (2013). Titania photocatalysis beyond recombination: a critical review. Catalysts, $3(4), \quad 942-953$. D O : $10.3390 /$ catal 3040942

[22] Janczarek, M., Kowalska, E. (2017). On the origin of enhanced photocatalytic activity of copper-modified titania in the oxidative reaction systems. Catalysts, 7(11), 317. DOI: 10.3390/catal7110317

[23] Hua, Z., Dai, Z., Bai, X., Ye, Z., Wang, P., Gu, H., Huang, X. (2016). Copper nanoparticles sensitized TiO2 nanotube arrays electrode with enhanced photoelectrocatalytic activity for diclofenac degradation. Chemical Engineering Journal, 283, 514-523. DOI: 10.1016/j.cej.2015.07.072 
[24] Slamet, S., Nasution, H.W., Purnama, E., Kosela, S., Gunlazuardi, J. (2005). Photocatalytic reduction of $\mathrm{CO}_{2}$ on copper-doped Titania catalysts prepared by improved-impregnation method. Catalysis Communications, 6(5), 313-319. DOI: 10.1016/j.catcom.2005.01.011

[25] Khemthong, P., Photai, P., Grisdanurak, N. (2013). Structural properties of $\mathrm{CuO} / \mathrm{TiO}_{2}$ nanorod in relation to their catalytic activity for simultaneous hydrogen production under solar light. International Journal of Hydrogen Energy, 38(36), 15992-16001. DOI: 10.1016/j.ijhydene.2013.10.065

[26] Xu, S., Du, A.J., Liu, J., Ng, J., Sun, D.D. (2011). Highly efficient CuO incorporated $\mathrm{TiO}_{2}$ nanotube photocatalyst for hydrogen production from water. International Journal of Hydrogen Energy, 36(11), 6560-6568. DOI: 10.1016/j.ijhydene.2011.02.103

[27] Yu, J., Hai, Y., Jaroniec, M. (2011). Photocatalytic hydrogen production over $\mathrm{CuO}$ modified titania. Journal of Colloid and Interface Science, 357(1), 223-228. DOI: 10.1016/j.jcis.2011.01.101
[28] Wade, L.G. (2006). Organic Chemistry. International Editions, 396-400. ISBN 978-0-32176841-4 (0-321-76841-8, 8th Edition, Publisher : Pearson

[29] Azam, M.M., Waris, A., Nahar, N. (2005). Prospects and potential of fatty acid methyl esters of some non-traditional seed oils for use as biodiesel in India. Biomass and Bioenergy, 29(4), 293-302. D I : 10.1016/j.biombioe.2005.05.001

[30] Nasralla, N.H., Yeganeh, M., Astuti, Y., Piticharoenphun, S., Siller, L. (2018). Systematic study of electronic properties of Fe-doped $\mathrm{TiO} 2$ nanoparticles by X-ray photoemission spectroscopy. Journal of Materials Science: Materials in Electronics, 29(20), 1795617966. DOI: $10.1007 / \mathrm{s} 10854-018-9911-5$

[31] Zhou, L., Deng, J., Zhao, Y., Liu, W., An, L., Chen, F. (2009). Preparation and characterization of $\mathrm{N}-\mathrm{I}$ co-doped nanocrystal anatase $\mathrm{TiO} 2$ with enhanced photocatalytic activity under visible-light irradiation. Materials Chemistry and Physics, 117(2-3), 522-527. DOI: 10.1016/j.matchemphys.2009.06.036 